\title{
Poczucie niepełnosprawności a percepcja siebie i objawy depresji u osób dorosłych z głuchotą postlingwalną korzystających z implantu ślimakowego
}

\section{Sense of disability and self-perception and symptoms of depression in adult postlingually deaf cochlear implant users}

\section{Joanna Kobosko}

Instytut Fizjologii i Patologii Słuchu, Światowe Centrum Słuchu, Klinika Rehabilitacji, Warszawa/Kajetany

Adres autora: Joanna Kobosko, Światowe Centrum Słuchu, Klinika Rehabilitacji, ul. Mokra 17, Kajetany, 05-830 Nadarzyn, e-mail: j.kobosko@ifps.org.pl

\section{Streszczenie}

\begin{abstract}
Wstęp: Poczucie niepełnosprawności jest subiektywnym stanem doświadczanym często niezależnie od obiektywnych przejawów niepełnosprawności wrodzonej czy nabytej, np. głuchoty. Wykazuje związek z akceptacją niepełnosprawności i zdrowiem psychicznym danej osoby. Celem pracy jest ocena nasilenia poczucia niepełnosprawności i zbadanie jego związków z percepcją siebie, doświadczanymi objawami depresji i zmiennymi socjodemograficznymi, takimi jak: płeć, wiek, wykształcenie, status małżeński (partnerski), status zatrudnienia, oraz zmiennymi związanymi z głuchotą: czas doświadczania głuchoty i czas korzystania z implantu ślimakowego (CI), u osób z głuchotą postlingwalną z CI.
\end{abstract}

Materiał i metody: Badaniami objęto 94 osoby z głuchotą postlingwalną, nabytą w wieku powyżej 3 i pół roku, w tym 56 kobiet i 38 mężczyzn, którzy uczestniczyli w hospitalizacjach rehabilitacyjnych organizowanych przez Klinikę Rehabilitacji Instytutu Fizjologii i Patologii Słuchu (IFPS). Wiek badanych mieścił się w przedziale od 23 do 81 lat, wszyscy korzystali z jednego implantu ślimakowego, który otrzymali po 18 roku życia, a czas doświadczania głuchoty zawierał się w przedziale od 1 roku do 55 lat. Czas korzystania z CI wynosił od pół roku do 11 lat. Do opisu percepcji siebie, w tym także w wymiarze niepełnosprawności, posłużono się Kwestionariuszem Ja-Inni (modyfikacja Kwestionariusza Cech wg M. Jarymowicz), a nasilenie objawów depresji mierzono z wykorzystaniem kwestionariusza Beck Depression Inventory (BDI).

Wyniki: Poczucie niepełnosprawności o średnim i wysokim nasileniu doświadcza 58,4\% biorących udział w badaniu. Z większym poczuciem niepełnosprawności wykazuje istotny związek spostrzeganie siebie w porównaniu z innymi ludźmi jako głupszego, słabszego, niesamodzielnego, samotnego i nieśmiałego, natomiast z mniejszym poczuciem niepełnosprawności wiąże się spostrzeganie siebie jako słyszącego, lubianego, wesołego i atrakcyjnego fizycznie (ANOVA). Osoby postlingwalnie ogłuchłe z CI o większym poczuciu niepełnosprawności spostrzegają siebie ogólnie mniej pozytywnie, jak i bardziej negatywnie $\mathrm{w}$ porównaniu $\mathrm{z}$ tymi z niskim poczuciem niepełnosprawności. Poczucie niepełnosprawności okazało się być istotnie wyższe u osób młodszych (poniżej 60 lat) w porównaniu ze starszymi. Ponadto większego poczucia niepełnosprawności należy spodziewać się u osób doświadczających objawów depresyjnych.

Wnioski: Osoby z głuchotą postlingwalną z CI, które mają nasilone poczucie niepełnosprawności związane z byciem osobą głuchą (ale nie tylko) potrzebują różnych form interwencji psychologicznej. Poczucie niepełnosprawności wraz z innymi pozostającymi z nim w istotnym związku cechami percepcji siebie wyraźnie tworzą „syndrom niepełnosprawności” w obrazie psychologicznego funkcjonowania osób z głuchotą postlingwalną z CI, który najprawdopodobniej ma charakter uniwersalny, a więc stosuje się też do osób z niepełnosprawnością inną niż głuchota. Poczucie niepełnosprawności pozostaje w dodatnim związku z objawami depresji. Podsumowując, niepełnosprawność stanowi ważny wymiar doświadczania siebie przez osoby z głuchotą postlingwalną z CI, a poczucie niepełnosprawności może także wskazywać, jak dana osoba radzi sobie ze swoją niepełnosprawnością.

Słowa kluczowe: poczucie niepełnosprawności • percepcja siebie • depresja • głuchota postlingwalna • implant ślimakowy • syndrom niepełnosprawności 


\section{Abstract}

Introduction: Sense of disability is a subjective state experienced often irrespectively of the objective signs of the congenital or acquired handicap such as deafness. It is related to the acceptance of disability and mental health of given person. The aim of this study was the assessment of the intensity of the sense of disability and analysis of its relationship to self-perception, depression symptoms and socio-demographic variables such as sex, age, education, marital (partnership) status, employment and deafness-related variables: duration of deafness and time from cochlear implantation (CI) in postlingually deaf cochlear implant users.

Material and methods: Study included 94 individuals with postlingual deafness acquired at age above 3.5 years; 56 women and 38 men; participating in the extended rehabilitation stays organized by the Rehabilitation Clinic of the Institute of Physiology and Pathology of Hearing. Age range of participants was between 23 and 81 years. All had one implant, have been implanted after 18 years old. Duration of deafness was between 1 and 55 years. CI experience was between half year and 11 years. Selfperception, also in terms of disability, was evaluated using I-Others Questionnaire (modified Kwestionariusz Cech - Attribute Questionnare by M. Jarymowicz), and intensity of depression symptoms was measured using Beck Depression Inventory (BDI).

Results: Among study participants, 58.4\% experienced sense of disability with medium to high intensity. Stronger sense of disability is significantly related with perception of oneself in comparison to other people as more stupid, weaker, dependent, lonely and shy, while weaker sense of disability is related to perceiving oneself as more able to hear, more likeable, cheerful and attractive (ANOVA). Postlingually deafened CI users with stronger sense of disability perceive themselves in general less favorably and more negatively compared to individuals with lesser sense of disability. Sense of disability has been found to be significantly stronger in younger individuals (below 60 years) compared to the older people. Moreover, stronger feeling of disability may be expected to be found in individuals experiencing more depressive symptoms.

Conclusions: Postlingually deafened CI users who have increased sense of disability connected to being deaf (but not only) require various forms of psychological intervention. Sense of disability, with other significantly related qualities of self-perception, form a distinct 'disability syndrome' in the picture of psychological functioning of the postlingually deaf CI users. Most likely this syndrome has universal character and thus may apply also to people with other types of disabilities, not only deafness. Sense of disability is positively related with depression symptoms. Summarizing, disability is an important dimension of self-image in the postlingually deaf CI users. Level of the sense of disability may also indicate how well is that person coping with disability.

Key words: sense of disability • self-perception • depression • postlingual deafness $\bullet$ cochlear implant $\bullet$ disability syndrome

\section{Wprowadzenie}

Poczucie niepełnosprawności jest stanem subiektywnym i wiąże się zazwyczaj ze skutkami posiadanej, wrodzonej lub nabytej wady czy deficytu, w tym np. utraty słuchu, albo ogólnie z utratą zdrowia. Można sądzić, że nasilenie tego stanu psychicznego wynika także z innych, psychologicznych uwarunkowań, do jakich należy m.in. samoocena czy dotychczasowe doświadczenia emocjonalne w życiu danej osoby, która jest lub staje się osobą niepełnosprawną. Niepetnosprawny, w definicji podanej przez Stownik języka polskiego, to „taki, który nie osiąga pełnej sprawności fizycznej lub psychicznej” [1]. Osoba, która „obiektywnie" posiada dowolną niepełnosprawność w stopniu znacznym może mieć niewielkie poczucie niepełnosprawności, jak i na odwrót, co rodzi pytanie o psychologiczną naturę samego poczucia niepełnosprawności.

Pojęcie niepełnosprawności w związku z utratą słuchu pojawia się w literaturze przedmiotu jako hearing disability $\mathrm{i}$ hearing handicap (co w języku polskim tłumaczy się zazwyczaj jako „niepełnosprawność słuchowa” bez różnicowania ze względu na odmienne oryginalne znaczenie tych dwóch pojęć). Pierwsze $\mathrm{z}$ wymienionych określeń: hearing disability obejmuje wszelkie ograniczenia związane $\mathrm{z}$ niepełnosprawnością słuchową, a obecne w funkcjonowaniu osób z uszkodzeniem narządu słuchu w sferze percepcji słuchowej dźwięków mowy i otoczenia oraz trudności w komunikowaniu się drogą słuchową w różnych sytuacjach społecznych. Drugie z przywołanych określeń to hearing handicap, wyrażające ten aspekt niepełnosprawności słuchowej, który wiąże się z „oceną przez daną osobę, która słuch utraciła, wpływu utraty słuchu na codzienne doświadczenia i funkcjonowanie psychospołeczne" [2].

Badacze ze Szwecji: Helvik, Jacobsen i Hallberg (2006) [3] zaproponowali, by zamiast o niepełnosprawności słuchowej (ang. hearing disability) mówić o ograniczeniach powstałych wskutek utraty słuchu, przejawiających się trudnościami w zrozumieniu tego, co mówią inni w pomieszczeniach, w których obecny jest hałas w tle, w rozmowach $w$ grupie, czy nawet $\mathrm{w}$ prowadzeniu konwersacji z jedną osobą, jak i w słyszeniu dźwięków innych niż mowa ludzka, a więc dzwonka do drzwi, telefonu, kroków czy percepcji muzyki. Wyodrębniają oni także niepełnosprawność doświadczaną emocjonalnie i społecznie jako negatywne skutki utraty słuchu w postaci ograniczeń $\mathrm{w}$ uczestniczeniu $\mathrm{w}$ relacjach interpersonalnych $\mathrm{w}$ rodzinie, jak i w środowisku pracy, czy w innych społecznych aktywnościach (zamiast: ang. hearing handicap). Propozycja ta wyraźnie odwołuje się do Międzynarodowej Klasyfikacji Funkcjonowania, Niepełnosprawności i Zdrowia (ang. International Classification of Functioning, Disability and Health, ICF), wprowadzonej w życie w 2001 roku. W nawiązaniu do tej klasyfikacji niepełnosprawność (ang. disability) obejmuje zatem dotychczasowe trzy możliwe kategorie służące opisowi stanu osoby niepełnosprawnej: 1) niesprawność (ang. impairment), która oznacza 
„każdą utratę sprawności lub nieprawidłowość w budowie czy funkcjonowaniu organizmu pod względem psychologicznym, psychofizycznym lub anatomicznym" [4, s. 14], 2) niepełnosprawność (ang. disability) definiuje się jako „każde ograniczenie bądź niemożność (wynikające z niesprawności) prowadzenia aktywnego życia w sposób lub w zakresie uznawanym za typowy dla człowieka" [jw.], 3) ograniczenia w pełnieniu ról społecznych (ang. handicap), tj. „ułomność określonej osoby wynikająca z niesprawności lub niepełnosprawności, ograniczająca lub uniemożliwiająca pełną realizację roli społecznej odpowiadającej wiekowi, płci oraz zgodnej ze społecznymi i kulturowymi uwarunkowaniami” [jw.]. Kategoryzacja ta niewiele jednak wnosi do zagadnienia poczucia niepełnosprawności, które charakteryzować może osobę niepełnosprawną $\mathrm{w}$ różnym stopniu i wymiarach.

Z psychologicznej perspektywy niepełnosprawnymi mogą czuć się nie tylko osoby, które utraciły sprawność czy zdrowie, a więc ogłuchłe postlingwalnie, lecz także m.in. młodzież z głuchotą prelingwalną, tj. głucha od urodzenia lub ogłuchła w okresie przed opanowaniem mowy i języka [57]. Znaczącym wymiarem doświadczania siebie przez słyszące matki dorastających głuchych młodych ludzi okazała się właśnie niepełnosprawność, a więc matki te w porównaniu z matkami dzieci słyszących czują się bardziej niepełnosprawne, chociaż to nie one, lecz ich dzieci są głuche [8]. Przytoczone rezultaty badań wskazują, iż niepełnosprawność stanowi ważny wymiar osobowej tożsamości młodzieży g/Głuchej ${ }^{1}$ mającej rodziców słyszących, jak i tożsamości macierzyńskiej słyszących matek młodzieży głuchej. Jak wynika choćby z powyżej przytoczonych badań, poczucie niepełnosprawności nie jest tożsame $\mathrm{z}$ istniejącą niepełnosprawnością, a tym bardziej z myśleniem, że ta osoba, która audiologicznie (obiektywnie) jest „bardziej głucha" doświadcza w większym stopniu poczucia niepełnosprawności niż ta, która lepiej słyszy. Zatem obiektywny niejako stopień niepełnosprawności nie znajduje prostego przełożenia na poczucie niepełnosprawności. Z badań wynika, że osoby dorosłe z głuchotą postlingwalną czują się znacznie bardziej niepełnosprawne niż osoby prelingwalnie głuche [9].

W ciągu dziesięcioleci powstawały różne narzędzia kwestionariuszowe do pomiaru subiektywnie doświadczanej niepełnosprawności w związku z utratą słuchu. Przykład stanowi skala Hearing Handicap Inventory (HHI) [10], istniejąca też w wersji dla osób starszych jako Hearing Handicap Inventory for the Elderly (HHIE) [10,11], służąca do oceny niepełnosprawności związanej z ubytkiem słuchu w kategoriach reakcji emocjonalnej na nią, jak i społecznej. Do drugiej generacji narzędzi przeznaczonych do pomiaru nasilenia niepełnosprawności u osób z postlingwalną utratą słuchu zalicza się m.in. Hearing Measurement Scale (HMS) [Noble, Atherley, 1970; za: 11] do pomiaru niepełnosprawności słuchowej rozumianej jako hearing disability oraz hearing handicap, której wynik oblicza się oddzielnie dla tych dwóch wyodrębnionych obszarów niepełnosprawności doświadczanej w związku z utratą słuchu, a także jako wynik globalny nasilenia niepełnosprawności.
W innej skali o nazwie Hearing Disability and Handicap Scale (HDHS), opracowanej przez międzynarodowy zespół badaczy [za: 3], także wyodrębniono zarówno niepełnosprawność definiowaną jako hearing disability, jak $\mathrm{i}$ hearing handicap. Zmiany w percepcji niepełnosprawności (ang. hearing handicap) przez osoby dorosłe z głuchotą postlingwalną można uznać za czuły wskaźnik skuteczności dopasowania aparatów słuchowych i korzyści z nich [10], a także - jak można sądzić - korzyści z implantu ślimakowego (ang. cochlear implant, CI).

Niektórzy badacze, jak np. de Graaf i Bijl z Holandii, zagadnienie poczucia niepełnosprawności traktowali jako element szerszego konstruktu, jakim jest akceptacja głuchoty, a więc ich zdaniem ci, którzy akceptują utratę słuchu (głuchotę), czują się mniej niepełnosprawni [9].

\section{Głuchota postlingwalna i jej psychologiczne konsekwencje a implanty ślimakowe}

Z głuchotą postlingwalną mamy do czynienia wówczas, gdy utrata słuchu nastąpiła w okresie po opanowaniu mowy i języka, a więc przyjmuje się, że po 3 i pół roku życia [13].

Głuchota nabyta (lub inna niepełnosprawność nabyta) wiąże się na ogół z doświadczeniem traumy i utraty, jak i jej dalszymi konsekwencjami dla życia danej osoby [14,15]. Utrata słuchu skutkuje najogólniej mówiąc ograniczeniami w słyszeniu i komunikowaniu się z innymi ludźmi drogą słuchową [16-19]. Tego rodzaju utrata zdrowia pociąga za sobą także konsekwencje psychologiczne, jak np. zmiany w obrębie percepcji siebie $[9,20]$, stanie psychicznym i samopoczuciu $[9,21,22]$ zwłaszcza u osób młodych i w wieku średnim [20], w formie rozlicznych konsekwencji społecznych czy związanych z zatrudnieniem [23].

Z perspektywy psychologicznej poczucie niepełnosprawności zależy też od etapu przeżywania procesu żałoby doświadczanej jako psychiczna reakcja na utratę słuchu, a więc od tego, jak dana osoba radzi sobie $\mathrm{z}$ tą utratą (co jednak nie jest przedmiotem niniejszych badań). Głuchota (czy niedosłuch) zazwyczaj staje się od momentu doświadczenia utraty słuchu ważnym wymiarem odróżniania siebie od innych ludzi, a więc osobowej tożsamości „osoby z niepełnosprawnością (głuchotą)”, podobnie jak i w przypadku innych niepełnosprawności $[19,24]$.

Interwencja medyczna $\mathrm{w}$ formie wszczepienia implantu ślimakowego osobie, która słuch utraciła, tj. z głuchotą postlingwalną, okazała się wysoce efektywna zarówno w obszarze percepcji słuchowej dźwięków mowy i komunikowania się drogą słuchową z otoczeniem, jak i w sferze poprawy jakości życia i dobrostanu psychicznego [25-28]. Pierwszym pacjentem, który otrzymał implant ślimakowy w Polsce w roku 1992, był mężczyzna postlingwalnie ogłuchły [29]. Jednakże wciąż niewiele wiadomo o poczuciu niepełnosprawności tej grupy osób.

\footnotetext{
1. Pisownia dużą literą G na wzór tradycji amerykańskiej odnosi się do modelu głuchoty, w którym ludzie głusi uznawani są za mniejszość językową i kulturową, natomiast pisownia małą literą g wskazuje na audiologiczne kryterium głuchoty, tj. posiadanie jej w stopniu znacznym bądź głębokim.
} 
Głuchota postlingwalna a percepcja niepełnosprawności doświadczanej wskutek utraty słuchu i psychiczny dystres ${ }^{2}$

Percepcja niepełnosprawności, doświadczanej wskutek utraty słuchu (rozumianej globalnie jako disability i handicap), współwystępuje z obecnością większego nasilenia ogólnego psychicznego dystresu, lecz nie objawów depresji u osób z głuchotą nabytą będących w wieku od 55 do 74 lat badanych w Szwecji [31]. W późniejszych badaniach przeprowadzonych także w Szwecji wykazano, że z większym psychicznym dobrostanem osób postlingwalnie ogłuchłych współwystępuje niższy poziom ograniczeń w aktywności i uczestnictwie, oceniany z zastosowaniem Hearing Disability and Handicap Inventory (HDHI) [3]. Poczucie niepełnosprawności (ang. feeling handicapped) dodatnio koreluje z doświadczaniem psychicznego dystresu u osób z głuchotą postlingwalną, jak wykazali de Graaf i Bijl (2002) [9], a także depresji w grupie osób powyżej 54 lat $\mathrm{z}$ utratą słuchu różnego stopnia badanych w Australii [12]. Należy dodać, iż populacja osób z głuchotą postlingwalną cierpi na większe nasilenie objawów depresji i zaburzenia depresyjne niż populacja ogólna [32], choć nie stwierdzono tej zależności na przykład w Australii [21]. Jeśli chodzi o użytkowników implantów ślimakowych, którzy doświadczyli utraty słuchu w stopniu głębokim i znacznym, rezultaty badań nie są jednoznaczne, gdyż wskazują zarówno na podobne występowanie nasilenia symptomów depresyjnych w porównaniu z populacją ogólną [33], jak i na większe niż u ludzi słyszących [34].

W Australii badaniami objęto osoby z uszkodzeniami narządu słuchu w wieku od 28 do 96 lat, które dokonywały oceny własnej niepełnosprawności będącej efektem utraty słuchu z wykorzystaniem Hearing Handicap Inventory for Adults - Screening Version (HHIA-S) [21]. Otrzymano istotną dodatnią zależność między poziomem doświadczanej niepełnosprawności (niska, średnia, wysoka) a ogólnym psychicznym dystresem: wzrostowi nasilenia niepełnosprawności wskutek utraty słuchu w percepcji badanych osób towarzyszy wyższy poziom doświadczanego $w$ ich ocenie psychicznego dystresu. Z kolei w Japonii w badaniach osób starszych powyżej 65 roku życia $\mathrm{z}$ zastosowaniem Hearing Handicap Inventory for the Elderly - Shortened Version (HHIE-S) badacze Saito i wsp. [11] wyodrębnili dwie grupy osób: „bez poczucia niepełnosprawności” spowodowanej utratą (pogorszeniem) słyszenia i „z poczuciem niepełnosprawności". W badanej grupie z poczuciem niepełnosprawności w związku z utratą słuchu znalazło się istotnie więcej mężczyzn, osób starszych i obciążonych historią poważnych chorób, osób $\mathrm{z}$ większym ubytkiem słuchu stwierdzonym $\mathrm{w}$ wynikach audiometrii tonalnej i korzystających z aparatów słuchowych. Objęci badaniami nie różnili się natomiast poziomem wykształcenia. Ci z poczuciem niepełnosprawności związanej ze słuchem uzyskali wyższe nasilenie symptomów depresyjnych mierzonych Geriatric Depression Scale (GDS-5). Ponadto poczucie niepełnosprawności (lecz nie rezultat pomiaru uszkodzenia narządu słuchu metodą audiometrii) okazało się istotnym predyktorem doświadczanych objawów depresji w tej grupie badanych. Podobne wyniki otrzymano $\mathrm{w}$ innych badaniach: relacjonowane przez osoby z utratą słuchu nasilenie niepełnosprawności związane ze słuchem (ang. self-reported hearing handicap) objaśniało o wiele lepiej doświadczany psychiczny dystres niż mierzony audiometrycznie ubytek słuchu $[12,21,35]$.

Poczucie niepełnosprawności czy „syndrom poczucia niepełnosprawności” u osób z głuchotą postlingwalną? - pytania badawcze

Celem pracy jest rozszerzenie rozumienia poczucia niepełnosprawności doświadczanego przez osoby postlingwalnie ogłuchłe korzystające z implantu ślimakowego (CI) przez odpowiedź na następujące pytania badawcze:

1. Jaki jest rozkład i nasilenie poczucia niepełnosprawności u osób dorosłych z głuchotą postlingwalną korzystających z implantu ślimakowego (CI)?

2. Czy istnieje związek poczucia niepełnosprawności z czasem trwania głuchoty i czasem korzystania z implantu ślimakowego (CI) przez osoby dorosłe z głuchotą postlingwalną?

3. Czy istnieje związek poczucia niepełnosprawności ze zmiennymi socjodemograficznymi: płeć, wiek, wykształcenie, pozostawanie w związku małżeńskim (partnerskim), aktywność zawodowa (nauka) u osób z głuchotą postlingwalną korzystających $\mathrm{z}$ implantu ślimakowego $(\mathrm{CI})$ ?

4. Czy istnieje związek poczucia niepełnosprawności (niskie, średnie, wysokie) z percepcją siebie i doświadczaniem objawów depresji u osób dorosłych z głuchotą postlingwalną korzystających z implantu ślimakowego $(\mathrm{CI})$ ?

\section{Materiał i metody}

\section{Osoby badane}

Badaniami objęto 94 dorosłe osoby z głuchotą postlingwalną, tj. nabytą po ukończeniu 3 i pół roku [za: 13], w stopniu głębokim lub znacznym wg klasyfikacji BIAP, które korzystały z jednego implantu ślimakowego (CI). Wszczepienie implantu ślimakowego miało u nich miejsce po ukończeniu 18 roku życia, a czas użytkowania CI w momencie badań wynosił od pół roku do 11 lat. Na potrzeby analiz statystycznych wyodrębniono ze względu na: 1) wiek - grupę osób młodszych (do 60 lat) i starszych (powyżej 60 lat); 2) wykształcenie - osoby z wykształceniem niższym (podstawowym i średnim) i wyższym (półwyższym i wyższym); 3) status małżeński (partnerski) - osoby pozostające w związku małżeńskim (partnerskim) i osoby samotne; 4) status zatrudnienia (nauka) - osoby pracujące zawodowo (lub uczące się) i osoby niepracujące (emerytura, renta). Szczegółowe informacje odnośnie charakterystyki socjodemograficznej uczestników badań i danych związanych z głuchotą oraz korzystaniem z implantu ślimakowego zawiera tabela 1.

\section{Narzędzia badawcze}

Kwestionariusz Ja-Inni (załącznik 1) [36] wykorzystano celem opisu percepcji siebie przez osoby dorosłe z głuchotą postlingwalną, a jego prototyp stanowi Kwestionariusz Cech

\footnotetext{
2. Psychiczny dystres oznacza stres destruktywny, negatywny, w efekcie szkodliwy dla zdrowia, który przeżywa dana osoba ,po przekroczeniu punktu maksymalnej tolerancji stresu ze względu na osiągane korzyści” [30].
} 
Tabela 1. Dane socjodemograficzne oraz dane dotyczące głuchoty osób z głuchotą postlingwalną z implantem ślimakowym $(\mathrm{Cl})$ biorących udział w badaniach

Table 1. Socio-demographic and deafness-related data of the postlingually deaf $\mathrm{Cl}$ users participating in the study

\begin{tabular}{lrr}
\hline \multicolumn{1}{c}{ Dane socjodemograficzne } & \multicolumn{2}{c}{$\mathbf{N}(\%)$} \\
(n=94)
\end{tabular}

M. Jarymowicz [37,38], który stworzony został do badań eksperymentalnych w obszarze poznawczych koncepcji tożsamości. Kwestionariusz Ja-Inni służy do pomiaru natężenia wybranych 20 cech człowieka i spostrzegania ich na wymiarze „podobny - niepodobny” do innych. Wśród cech znajduje się 10 cech pozytywnych (np. dobry, wrażliwy, pomysłowy, lubiany) i 10 cech negatywnych (np. głupi, złośliwy, samotny, niepełnosprawny). Dokonano zmian w zawartości treściowej Kwestionariusza Cech, a zmodyfikowany zestaw 20 cech człowieka uwzględniał te cechy, które uznano za ważne w percepcji siebie u młodzieży głuchej, jak i ich słyszących matek, takie m.in. jak: słyszący, niepełnosprawny, samotny, atrakcyjny fizycznie, w odniesieniu do których został on zastosowany po raz pierwszy w tej wersji $[5,8,36]$.

Zadaniem osoby badanej jest zaznaczenie na siedmiopunktowej skali, jaka jest w porównaniu z innymi ludźmi
(„W porównaniu z innymi ludźmi jestem...”). Przykładowo, w odniesieniu do cechy niepetnosprawny, gdy zakreśli 4 (środek skali), oznacza to, że spostrzega siebie jako niepełnosprawną „tak samo jak inni”. Gdy z kolei zakreśli punkty od 1 do 3, oznacza to, iż czuje się odpowiednio dużo mniej (1), mniej (2) czy raczej mniej (3) niepełnosprawna niż inni. Gdy zakreśli punkty 5, 6 lub 7, oznacza to, że spostrzega siebie jako odpowiednio raczej bardziej (5) niepełnosprawną niż inni, bardziej (6) czy dużo bardziej (7) niepełnosprawną w porównaniu z innymi ludźmi. Policzono współczynnik a Cronbacha dla cech pozytywnych i cech negatywnych Kwestionariusza Ja-Inni oddzielnie i otrzymano dla osób postlingwalnie ogłuchłych, korzystających z implantu ślimakowego i biorących udział w badaniu, wartości odpowiednio 0,82 i 0,79.

Inwentarz Depresji Becka (Beck Depression Inventory, BDI), w tłumaczeniu na język polski M. Lewickiej i J. Czapińskiego, zastosowany został w celu pomiaru częstości, zróżnicowania i nasilenia objawów depresji. Kwestionariusz ten jest najbardziej rozpowszechniony i uznany jako trafne narzędzie diagnostyczne, także przesiewowe. Posiada 21 pozycji wielokrotnego wyboru, punktowanych na skali od 0 do 3, z których każda mierzy określony objaw depresji (np. smutek, bezsenność, wzmożoną męczliwość, poczucie winy, niechęć do siebie, dolegliwości somatyczne, utratę zainteresowań seksualnych czy myśli samobójcze), co daje maksymalną liczbę punktów 63. W instrukcji badany opisuje swój stan psychiczny i somatyczny, którego doświadcza w okresie ostatniego miesiąca. Przyjęto, zgodnie z ustaleniami w oryginalnym opracowaniu tego narzędzia [39], iż wynik ogólny powyżej 9 punktów może wskazywać na to, że dana osoba cierpi na depresję, co jednak wymaga dalszej diagnozy klinicznej. W badaniach polskich autorzy najczęściej odwołują się także do tego kryterium [40-42]. Inwentarz Depresji Becka posiada dobre właściwości psychometryczne [43]. W prezentowanym badaniu w odniesieniu do osób z głuchota postlingwalna z implantem ślimakowym otrzymano a Cronbacha o wartości 0,76 , podczas gdy w innych polskich badaniach, np. dotyczących osób, które w dzieciństwie przeżyły II wojnę światową, współczynnik ten wynosił 0,85 [41].

Ankieta informacyjna zawiera dane dotyczące właściwości socjodemograficznych osób uczestniczących w badaniu, a także informacje związane $\mathrm{z}$ czasem trwania głuchoty i korzystania z implantu ślimakowego (CI).

\section{Procedura}

Na przeprowadzenie niniejszych badań uzyskano zgodę Komisji Bioetycznej działającej przy Instytucie Fizjologii i Patologii Słuchu (IFPS) w Warszawie. Kwestionariusze oraz ankietę informacyjną osoby badane wypełniały anonimowo podczas tygodniowych hospitalizacji rehabilitacyjnych dla osób dorosłych z głuchotą postlingwalną korzystających z implantu ślimakowego ukierunkowanych na rehabilitację słuchu i mowy, organizowanych przez Klinikę Rehabilitacji IFPS. W analizie statystycznej wyników wykorzystano: test t-Studenta dla prób niezależnych, test chi $^{2}$, analizę regresji liniowej, analizę korelacji r Pearsona, analizę wariancji ANOVA. Obliczenia wykonane zostały w pakiecie SPSS wersja 16. 


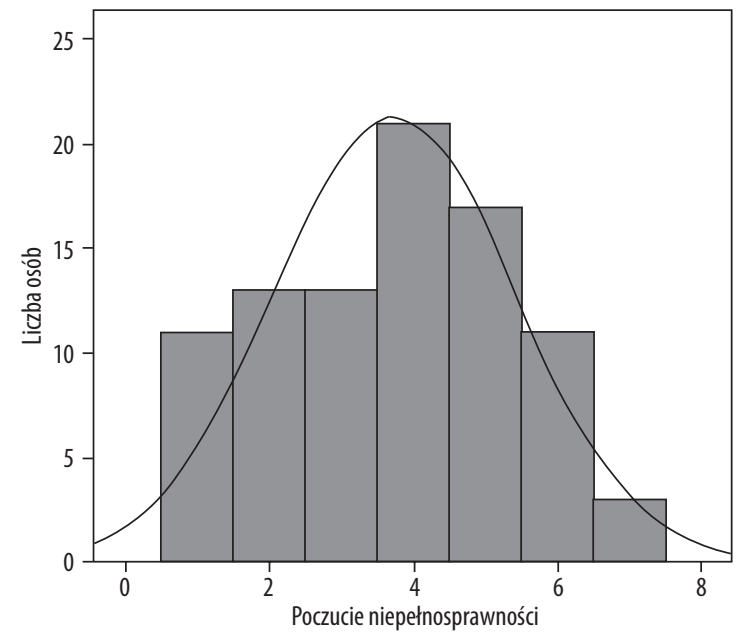

Rycina 1. Rozkład wyników poczucia niepełnosprawności (Kwestionariusz Ja-Inni - cecha Niepełnosprawny) u osób z głuchotą postlingwalną z implantem ślimakowym (Cl)

Figure 1. Distribution of results of the sense of disability (I-Others Questionnaire - attribute Disability) in the postlingually deaf cochlear implant $(\mathrm{Cl})$ users

\section{Wyniki}

Poczucie niepełnosprawności u osób z głuchota postlingwalną korzystających z implantu ślimakowego (CI)

Rozkład wyników nasilenia poczucia niepełnosprawności ( $\mathrm{M}=3,74 ; \mathrm{SD}=1,67 ; \mathrm{min}=1$, maks=7) w percepcji siebie u osób postlingwalnie ogłuchłych z implantem ślimakowym (CI) obrazuje rycina 1 . Uwzględniono na niej wyniki osób, które zaznaczyły odpowiedź w Kwestionariuszu Ja-Inni odnośnie cechy Niepełnosprawny $(\mathrm{n}=89)$.

Na potrzeby dalszych analiz przyjęto, że osoby postlingwalnie ogłuchłe z CI, które zaznaczyły, że są „bardziej niepełnosprawne” (punkty 5, 6, 7), „tak samo niepełnosprawne” (punkt 4) czy „mniej niepełnosprawne” (punkty $1,2,3)$ w porównaniu $\mathrm{z}$ innymi ludźmi doświadczają poczucia niepełnosprawności o odpowiednio wysokim, średnim i niskim nasileniu (rycina 2). W tak podzielonej grupie badawczej poczucie niepełnosprawności niskie prezentuje $41,6 \%$ osób, średnie $23,6 \%$, a wysokie $34,8 \%$ osób badanych.

Poczucie niepełnosprawności u osób z głuchotą postlingwalną korzystających z implantu ślimakowego (CI) a zmienne socjodemograficzne i zmienne związane $\mathrm{z}$ głuchotą

U osób postlingwalnie ogłuchłych z CI stwierdzono jedynie związek wieku z poczuciem niepełnosprawności, a więc osoby młodsze (poniżej 60 lat) spostrzegają siebie $\mathrm{w}$ istotnie większym stopniu jako niepełnosprawne w porównaniu z osobami starszymi (powyżej 60 lat) (rycina 3). Pozostałe zmienne socjodemograficzne: płeć, wykształcenie, status małżeński (partnerski) i status zatrudnienia nie pozostawały w związku z poczuciem niepełnosprawności (tabela 2).
Poczucie niepełnosprawności nie koreluje istotnie z czasem doświadczania głuchoty, ani też z czasem korzystania $\mathrm{z}$ implantu ślimakowego przez osoby z głuchotą postlingwalną.

Poczucie niepełnosprawności u osób z głuchotą postlingwalną korzystających $\mathrm{z}$ implantu ślimakowego (CI) a percepcja siebie (Kwestionariusz Ja-Inni)

Okazało się, że z większym poczuciem niepełnosprawności osób z głuchotą postlingwalną z CI wiąże się percepcja siebie jako głupszego, słabszego, niesamodzielnego, samotnego i nieśmiałego, natomiast z mniejszym poczuciem niepełnosprawności wiąże się spostrzeganie siebie jako słyszącego, lubianego, wesołego, atrakcyjnego fizycznie - co obrazują wyniki jednoczynnikowej ANOVA i testów post hoc Bonferroniego (tabela 3, ryciny 4 i 5). Większe poczucie niepełnosprawności pozostaje $\mathrm{w}$ związku z większym nasileniem negatywnej percepcji siebie, a mniejszym nasileniem pozytywnej percepcji siebie ogółem (tabele 3 i 4).

Poczucie niepełnosprawności u osób z głuchotą postlingwalną korzystających z implantu ślimakowego (CI) a objawy depresji (BDI)

Rozkład wyników w Inwentarzu Depresji Becka (BDI) $(\mathrm{M}=6,01 ; \mathrm{SD}=4,82, \mathrm{~min}=0$, maks=26) uzyskanych przez osoby badane, które wypełniły kwestionariusz $(\mathrm{n}=69) \mathrm{w}$ całości, przedstawiono na rycinie 6. Wynik ogólny powyżej 9 punktów, sugerujący możliwość występowania depresji o różnym nasileniu, otrzymało $26 \%$ badanych osób ( $n=18)$. Nie stwierdzono różnic istotnych statystycznie odnośnie nasilenia doświadczanych objawów depresji ze względu na płeć, wiek ( $\leq 60$ i >60 lat), wykształcenie („niższe” i „wyższe”), aktywność zawodową (tak lub nie) czy pozostawanie z związku małżeńskim (partnerskim) (tak lub nie) u osób postlingwalnie ogłuchłych z CI. Ponadto okazało się, że czas doświadczania głuchoty i czas korzystania z CI nie pozostaje w związku z tym, jakiego nasilenia objawów depresji doświadczają badani.

Natomiast między poczuciem niepełnosprawności a objawami depresji istnieje słaba dodatnia, lecz istotna zależność $(\mathrm{r}=0,26 ; \mathrm{p}<0,05)$, a więc u osób z głuchotą postlingwalną z CI o wyższym poczuciu niepełnosprawności należy spodziewać się większego nasilenia symptomów depresji.

\section{Dyskusja}

Podjęte badania dotyczą poczucia niepełnosprawności doświadczanego przez osoby dorosłe z głuchotą postlingwalną, korzystające $\mathrm{z}$ implantu ślimakowego (CI), jak i jego związków z percepcją siebie oraz objawami depresji, a także ze zmiennymi socjodemograficznymi i zmiennymi dotyczącymi głuchoty.

Okazało się, że wysokie poczucie niepełnosprawności w porównaniu z innymi ludźmi posiada $34 \%$ osób badanych. Można sądzić, że średnie nasilenie tego poczucia dla całej grupy (cecha Niepełnosprawny - M=3,67) jest znacząco wyższe niż wskazują na to wyniki uzyskane przez młodych dorosłych z głuchotą prelingwalną, otrzymane wcześniej z zastosowaniem tego samego 
Tabela 2. Poczucie niepełnosprawności (Kwestionariusz Ja-Inni - cecha Niepełnosprawny; średnia, odchylenie standardowe) a zmienne socjodemograficzne w grupie osób z głuchotą postlingwalną z implantem ślimakowym $(\mathrm{Cl})$ - wyniki porównań średnich (test t-Studenta)

Table 2. Sense of disability (I-Others Questionnaire - attribute Disability; mean, standard deviation) vs. socio-demographic data of the postlingually deaf $\mathrm{Cl}$ users - comparison of mean values (t-Student's test)

\begin{tabular}{|c|c|c|c|}
\hline Zmienne socjodemograficzne & Poczucie niepełn & awności (Ja-Inni) & $\begin{array}{c}\text { Test } \\
\text { t-Studenta }\end{array}$ \\
\hline $\begin{array}{l}\text { Kobieta }(n=51) \\
\text { Mężczyzna }(n=38)\end{array}$ & $\begin{array}{l}3,59 \\
3,92\end{array}$ & $\begin{array}{r}(1,79) \\
(1,5)\end{array}$ & $t=-0,93 ; p>0,05$ \\
\hline $\begin{array}{l}\text { Wiek } \\
\text { Młodsi ( } \leq 60 \text { lat) }(n=57) \\
\text { Starsi (>60 lat) }(n=32)\end{array}$ & $\begin{array}{r}4 \\
3,25\end{array}$ & $\begin{array}{l}(1,61) \\
(1,68)\end{array}$ & $t=2,07^{\star}$ \\
\hline $\begin{array}{l}\text { Wykształcenie } \\
\quad \text { Niższe (podstawowe + średnie) }(\mathrm{n}=55) \\
\text { Wyższe (półwyższe + wyższe) }(\mathrm{n}=29)\end{array}$ & $\begin{array}{l}3,76 \\
3,66\end{array}$ & $\begin{array}{r}(1,65) \\
(1,8)\end{array}$ & $t=-0,32 ; p>0,05$ \\
\hline $\begin{array}{l}\text { Status małżeński (partnerski) } \\
\text { Pozostaje w związku }(n=64) \\
\text { Nie pozostaje w związku }(n=25)\end{array}$ & $\begin{array}{l}3,77 \\
3,64\end{array}$ & $\begin{array}{l}(1,71) \\
(1,58)\end{array}$ & $t=-0,32 ; p>0,05$ \\
\hline $\begin{array}{l}\text { Zatrudnienie } \\
\text { Pracuje zawodowo }(n=44) \\
\quad \text { Nie pracuje zawodowo }(n=45)\end{array}$ & $\begin{array}{r}3,86 \\
3,6\end{array}$ & $\begin{array}{l}(1,64) \\
(1,71)\end{array}$ & $t=-0,74 ; p>0,05$ \\
\hline $\begin{array}{l}\text { Moment utraty słuchu } \\
\text { W okresie od } 3,5 \text { do } 6 \text { lat }(n=15) \\
\text { Powyżej } 7 \text { lat }(n=74)\end{array}$ & $\begin{array}{l}3,93 \\
3,69\end{array}$ & $\begin{array}{l}(1,44) \\
(1,72)\end{array}$ & $t=-0,51 ; p>0,05$ \\
\hline
\end{tabular}

* $p<0,05$

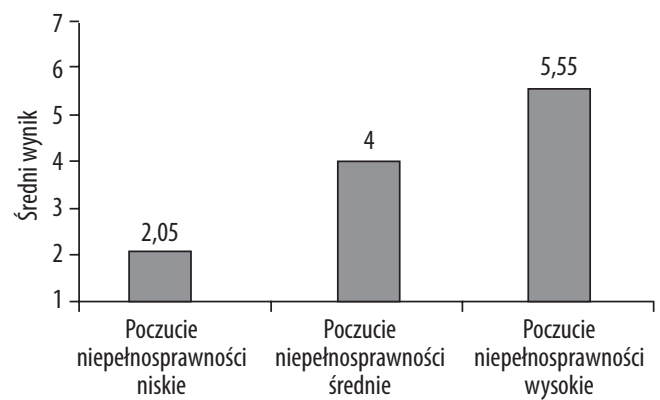

Rycina 2. Poczucie niepełnosprawności (Kwestionariusz Ja-Inni - cecha Niepełnosprawny - średnie) u osób z głuchotą postlingwalną z implantem ślimakowym $(\mathrm{Cl}) \mathrm{z}$ podziałem na grupy o poczuciu niepełnosprawności niskim, średnim i wysokim

Figure 2. Sense of disability (I-Others Questionnaire - attribute Disability - mean values) in the postlingually deaf $\mathrm{Cl}$ users, divided into groups with low, medium and high level of the sense of disability

narzędzia, Kwestionariusza Ja-Inni dla cechy Niepełnosprawny $(M=2,39)[5,36]$. Osoby $z$ głuchotą postlingwalną czują się zatem bardziej niepełnosprawne niż osoby (młode) prelingwalnie głuche, a wynik taki otrzymali także badacze z Holandii [9]. W przywoływanych badaniach aż $75 \%$ uczestniczących w nich osób z głuchotą postlingwalną przeżywało poczucie niepełnosprawności. Mając na względzie, iż nie korzystali oni $\mathrm{z}$ implantu ślimakowego, lecz w zdecydowanej większości z konwencjonalnych aparatów słuchowych, można postawić hipotezę o korzyściach, jakie najprawdopodobniej odnoszą użytkownicy implantów ślimakowych (na przykładzie badanych w Polsce), na

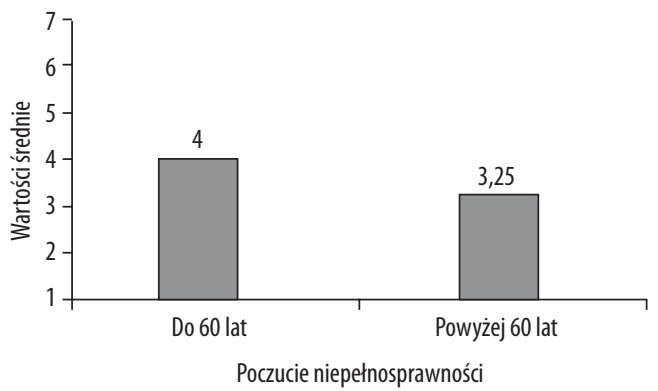

Rycina 3. Poczucie niepełnosprawności (Kwestionariusz JaInni - cecha Niepełnosprawny - średnie) u osób z głuchotą postlingwalną z implantem ślimakowym (Cl) „młodszych” ( $\leq 60$ lat) i ,starszych" (>60 lat)

Figure 3. Sense of disability (I-Others Questionnaire - attribute Disability - mean values) in postlingually deaf $\mathrm{Cl}$ users 'younger' ( $\leq 60$ years) and 'older' ( $>60$ years)

co wskazywałby uzyskany w niniejszych badaniach o wiele niższy procent tych, którzy czują się niepełnosprawni „bardziej od innych” w porównaniu z wynikami badań holenderskich [9].

Ponadto osoby młodsze, tj. w wieku 60 lat i poniżej, w porównaniu z osobami starszymi postligwalnie ogłuchłymi, będącymi powyżej 60 lat, doświadczają większego poczucia niepełnosprawności, co pozostaje $\mathrm{w}$ zgodności $\mathrm{z}$ innymi rezultatami badań na ten temat [20]. Na podstawie uzyskanych wyników można sądzić, że dla poczucia niepełnosprawności osób z głuchotą postlingwalną z CI 
Tabela 3. Kwestionariusz Ja-Inni - istotne statystycznie wyniki porównań średnich (ANOVA) uzyskanych przez osoby z głuchotą postlingwalną z implantem ślimakowym $(\mathrm{Cl})$ o niskim, średnim i wysokim poczuciu niepełnosprawności dla poszczególnych cech

Table 3. I-Others Questionnaire - statistically significant results of comparison of mean results (ANOVA) of the postlingually deaf $\mathrm{Cl}$ users with low, medium and high level of the sense of disability for individual attributes

\begin{tabular}{|c|c|c|c|c|c|c|}
\hline$J a-I n n i$ & $\begin{array}{l}\text { Poczucie niepełnosprawności } \\
\text { (PN) }\end{array}$ & \multicolumn{2}{|c|}{$M(S D)$} & df & $\mathbf{F}$ & Testy post hoc Bonferroniego \\
\hline \multirow[t]{4}{*}{ Głupi } & Niskie $(\mathrm{n}=37)$ & 2,35 & $(1,25)$ & \multirow{4}{*}{2,85} & \multirow{4}{*}{$4,07^{*}$} & \multirow{4}{*}{$\begin{array}{l}\text { Grupa o niskim PN istotnie różni się } \\
(p<0,05) \text { od grupy o wysokim PN }\end{array}$} \\
\hline & Średnie $(n=21)$ & 3,14 & $(1,15)$ & & & \\
\hline & Wysokie $(n=30)$ & 3,17 & $(1,46)$ & & & \\
\hline & Razem $(n=88)$ & 2,82 & $(1,35)$ & & & \\
\hline \multirow[t]{4}{*}{ Słyszący } & Niskie $(n=36)$ & 2,83 & $(1,23)$ & \multirow{4}{*}{2,85} & \multirow{4}{*}{$4.46^{*}$} & \multirow{4}{*}{$\begin{array}{l}\text { Grupa o niskim PN istotnie różni sie } \\
(p<0,05) \text { od grupy o wysokim PN }\end{array}$} \\
\hline & Średnie $(n=21)$ & 2,43 & $(0,93)$ & & & \\
\hline & Wysokie $(n=31)$ & 1,94 & $(1,39)$ & & & \\
\hline & Razem $(n=88)$ & 2,42 & $(1,27)$ & & & \\
\hline \multirow[t]{4}{*}{ Staby } & Niskie $(n=37)$ & 2,95 & $(1,29)$ & \multirow{4}{*}{2,86} & \multirow{4}{*}{$3,79^{\star}$} & \multirow{4}{*}{$\begin{array}{l}\text { Grupa o niskim PN istotnie różni się } \\
(p<0,05) \text { od grupy o wysokim PN }\end{array}$} \\
\hline & Średnie $(n=21)$ & 3,24 & $(0,94)$ & & & \\
\hline & Wysokie $(\mathrm{n}=31)$ & 3,71 & $(1,07)$ & & & \\
\hline & Razem $(n=89)$ & 3,28 & $(1,18)$ & & & \\
\hline \multirow[t]{4}{*}{ Niesamodzielny } & Niskie $(\mathrm{n}=37)$ & 1,92 & $(1,21)$ & \multirow{4}{*}{2,86} & \multirow{4}{*}{$9,6^{\star * *}$} & \multirow{4}{*}{$\begin{array}{l}\text { Grupa o niskim PN istotnie różni } \\
\text { się }(p<0,05) \text { od grupy o średnim PN, } \\
\text { a także o wysokim PN }(p<0,001)\end{array}$} \\
\hline & Średnie $(n=21)$ & 2,95 & $(1,24)$ & & & \\
\hline & Wysokie $(n=31)$ & 3,29 & $(1,53)$ & & & \\
\hline & Razem $(n=89)$ & 2,64 & $(1,46)$ & & & \\
\hline \multirow[t]{4}{*}{ Nieprzystojny } & Niskie $(n=37)$ & 2,78 & $(1,31)$ & \multirow{4}{*}{2,86} & \multirow{4}{*}{$6,73^{* *}$} & \multirow{4}{*}{$\begin{array}{l}\text { Grupa o niskim PN istotnie różni } \\
\text { się }(p<0,05) \text { od grupy o średnim PN } \\
\text { a także o wysokim PN }(p<0,01)\end{array}$} \\
\hline & Średnie $(n=21)$ & 3,71 & $(0,72)$ & & & \\
\hline & Wysokie $(n=31)$ & 3,65 & $(1,11)$ & & & \\
\hline & Razem ( $n=89)$ & 3,3 & $(1,2)$ & & & \\
\hline \multirow[t]{4}{*}{ Lubiany } & Niskie $(n=37)$ & 4,73 & $(0,96)$ & \multirow{4}{*}{2,86} & \multirow{4}{*}{$5,01^{* *}$} & \multirow{4}{*}{$\begin{array}{l}\text { Grupa o niskim PN istotnie różni się } \\
(p<0,05) \text { od grupy o średnim PN, } \\
\text { a także o wysokim PN }(p<0,05)\end{array}$} \\
\hline & Średnie $(n=21)$ & 4,0 & $(0,7)$ & & & \\
\hline & Wysokie $(n=31)$ & 4,13 & $(1,12)$ & & & \\
\hline & Razem ( $n=89)$ & 4,35 & $(1,01)$ & & & \\
\hline \multirow[t]{4}{*}{ Atrakcyjny fizycznie } & Niskie $(n=36)$ & 4,44 & $(1,25)$ & \multirow{4}{*}{2,85} & \multirow{4}{*}{$7,19^{* *}$} & \multirow{4}{*}{$\begin{array}{l}\text { Grupa o niskim PN istotnie różni się } \\
(p<0,01) \text { od grupy o wysokim PN }\end{array}$} \\
\hline & Średnie $(n=21)$ & 3,86 & $(0,57)$ & & & \\
\hline & Wysokie $(n=31)$ & 3,52 & $(0,93)$ & & & \\
\hline & Razem $(n=88)$ & 3,98 & $(1,08)$ & & & \\
\hline Wesoły & Niskie $(n=37)$ & 4,86 & $(1,16)$ & & & Grupa o niskim PN istotnie różni się \\
\hline & Średnie $(n=21)$ & 4,38 & $(1,02)$ & & & \\
\hline & Wysokie $(n=31)$ & 4,03 & $(1,22)$ & 2,00 & T ו & \\
\hline & Razem ( $n=89)$ & 4,46 & $(1,2)$ & & & \\
\hline
\end{tabular}




\begin{tabular}{|c|c|c|c|c|c|c|}
\hline \multirow{2}{*}{$\begin{array}{l}\qquad \boldsymbol{J a}-\mathbf{I n n i} \\
\text { Samotny }\end{array}$} & \multirow{2}{*}{$\begin{array}{l}\text { Poczucie niepetnosprawności } \\
\text { (PN) }\end{array}$} & \multicolumn{2}{|c|}{$M(S D)$} & \multirow{5}{*}{$\begin{array}{c}\mathbf{d f} \\
2,86\end{array}$} & \multirow{5}{*}{$\begin{array}{c}\mathbf{F} \\
9,71^{\star \star *}\end{array}$} & \multirow{5}{*}{$\begin{array}{l}\text { Testy post hoc Bonferroniego } \\
\text { Grupa o niskim PN istotnie różni się } \\
(p<0,01) \text { od grupy o średnim PN, } \\
\text { a także o wysokim PN }(p<0,01)\end{array}$} \\
\hline & & 2,32 & $(1,53)$ & & & \\
\hline & Średnie $(n=21)$ & 4,05 & $(1,56)$ & & & \\
\hline & Wysokie $(n=31)$ & 3,68 & $(1,74)$ & & & \\
\hline & Razem $(n=89)$ & 3,2 & $(1,77)$ & & & \\
\hline \multirow[t]{4}{*}{ Nieśmiały } & Niskie $(n=37)$ & 2,86 & $(1,47)$ & \multirow{4}{*}{2,86} & \multirow{4}{*}{$8,7^{* * *}$} & \multirow{4}{*}{$\begin{array}{l}\text { Grupa o niskim PN istotnie różni } \\
\text { się }(p<0,01) \text { od grupy o średnim PN, } \\
\text { a także o wysokim PN }(p<0,01)\end{array}$} \\
\hline & Średnie $(n=21)$ & 4,33 & $(1,32)$ & & & \\
\hline & Wysokie $(n=31)$ & 4,1 & $(1,62)$ & & & \\
\hline & Razem (n=89) & 3,64 & $(1,62)$ & & & \\
\hline \multirow[t]{4}{*}{ Ja pozytywne razem } & Niskie $(n=32)$ & 4,53 & $(0,87)$ & \multirow{4}{*}{2,79} & \multirow{4}{*}{$2,62^{* *}$} & \multirow{4}{*}{$\begin{array}{l}\text { Grupa o niskim PN istotnie różni się } \\
(p<0,01) \text { od grupy o wysokim PN }\end{array}$} \\
\hline & Średnie $(n=21)$ & 4,15 & $(0,4)$ & & & \\
\hline & Wysokie $(n=29)$ & 3,95 & $(0,62)$ & & & \\
\hline & Razem $(n=82)$ & 4,23 & $(0,72)$ & & & \\
\hline \multirow[t]{4}{*}{ Ja negatywne razem } & Niskie $(n=36)$ & 2,59 & $(0,79)$ & \multirow{4}{*}{2,83} & \multirow{4}{*}{$25,6^{\star \star \star}$} & \multirow{4}{*}{$\begin{array}{l}\text { Grupa o niskim PN istotnie różni się } \\
\text { (p<0,001) od grupy o średnim } \\
\text { i wysokim PN }\end{array}$} \\
\hline & Średnie $(n=20)$ & 3,64 & $(0,48)$ & & & \\
\hline & Wysokie $(n=30)$ & 3,67 & $(0,65)$ & & & \\
\hline & Razem (n=86) & 3,21 & $(0,86)$ & & & \\
\hline
\end{tabular}

${ }^{*} p<0,05 ;{ }^{* *} p<0,01 ;{ }^{* *} p<0,001$

nie ma istotnego znaczenia płeć, wykształcenie, aktywność zawodowa (nauka), pozostawanie lub nie w związku małżeńskim (partnerskim). Odwołując się do innych badań, w tym cytowanych we Wprowadzeniu, można było przypuszczać, że to mężczyźni ogłuchli postlingwalnie będą doświadczać większego poczucia niepełnosprawności niż kobiety oraz, że wykształcenie nie ma znaczenia w odniesieniu do percepcji siebie jako mniej lub bardziej niepełnosprawnego w porównaniu z innymi ludźmi [11]. Nie stwierdzono też związku czasu trwania głuchoty i czasu korzystania $\mathrm{z}$ implantu ślimakowego z poczuciem niepełnosprawności.

U osób dorosłych z głuchotą postlingwalną, korzystających $\mathrm{z}$ implantu ślimakowego, poczucie niepełnosprawności wiąże się ze specyficzną percepcją siebie w innych wymiarach osobowej tożsamości, a tym samym nie stanowi „wyizolowanej” właściwości psychologicznego funkcjonowania osoby ogłuchłej. Poczucie niepełnosprawności doświadczane przez osoby, które słuch utraciły, pozostaje w istotnej zależności ze spostrzeganiem siebie w sferze intelektualno-poznawczej jako głupszego od innych. Z kolei w sferze relacji interpersonalnych poczucie niepełnosprawności współwystępuje z samotnością, nieśmiałością, poczuciem bycia mniej lubianym i wesołym od innych. Spostrzegane właściwości osoby takie, jak niesamodzielność, (niska) atrakcyjność fizyczna, poczucie, że jest się słabszym $\mathrm{w}$ porównaniu $\mathrm{z}$ innymi, także współwystępują z poczuciem niepełnosprawności. Zastanawiające jest, że $\mathrm{z}$ większym poczuciem niepełnosprawności pozostaje w związku percepcja siebie osoby postlingwalnie ogłuchłej jako mniej słyszącej. Można przypuszczać, że możliwości słuchowe w zakresie percepcji mowy i efektywne komunikowanie się z wykorzystaniem implantu ślimakowego sprzyja zmniejszeniu poczucia niepełnosprawności w tej sferze. Należy mieć też na względzie, że samo spostrzeganie siebie jako bardziej słyszącego w porównaniu z innymi ludźmi może manifestować mechanizm obronny zaprzeczania własnej głuchocie. Stosowanie zaprzeczania jako strategii radzenia sobie ze stresem ma miejsce znacząco częściej u osób postlingwalnie głuchych z implantem ślimakowym niż u słyszących z populacji ogólnej [44].

Otrzymane wyniki dotyczące związku poczucia niepełnosprawności z innymi wymiarami percepcji siebie pokazują szerzej, czym jest poczucie niepetnosprawności doświadczane wskutek między innymi utraty zdolności słyszenia u osób z głuchotą postlingwalną. Poczucie niepełnosprawności można więc uznać za „syndrom (poczucia) niepełnosprawności” ze względu na stwierdzone w badaniach istotne współzależności $\mathrm{z}$ innymi wymiarami percepcji siebie (osobowej tożsamości). Syndrom ten ma prawdopodobnie charakter uniwersalny, a więc występuje u tych wszystkich, którzy z jakiegoś powodu, np. innego rodzaju niż głuchota niepełnosprawności czy przewlekłej choroby, doświadczają niepełnosprawności.

Ponadto z poczuciem niepełnosprawności, jak wykazano w innych badaniach, wiąże się rosnące nasilenie doświadczanego psychicznego dystresu u osób postlingwalnie ogłuchłych. Zależność ta została potwierdzona w niniejszym badaniu w odniesieniu do nasilenia objawów depresji, a więc $\mathrm{z}$ większym poczuciem niepełnosprawności współwystępują objawy depresyjne u osób postlingwalnie ogłuchłych korzystających z implantu ślimakowego. Podobna zależność między percepcją własnej niepełnosprawności 


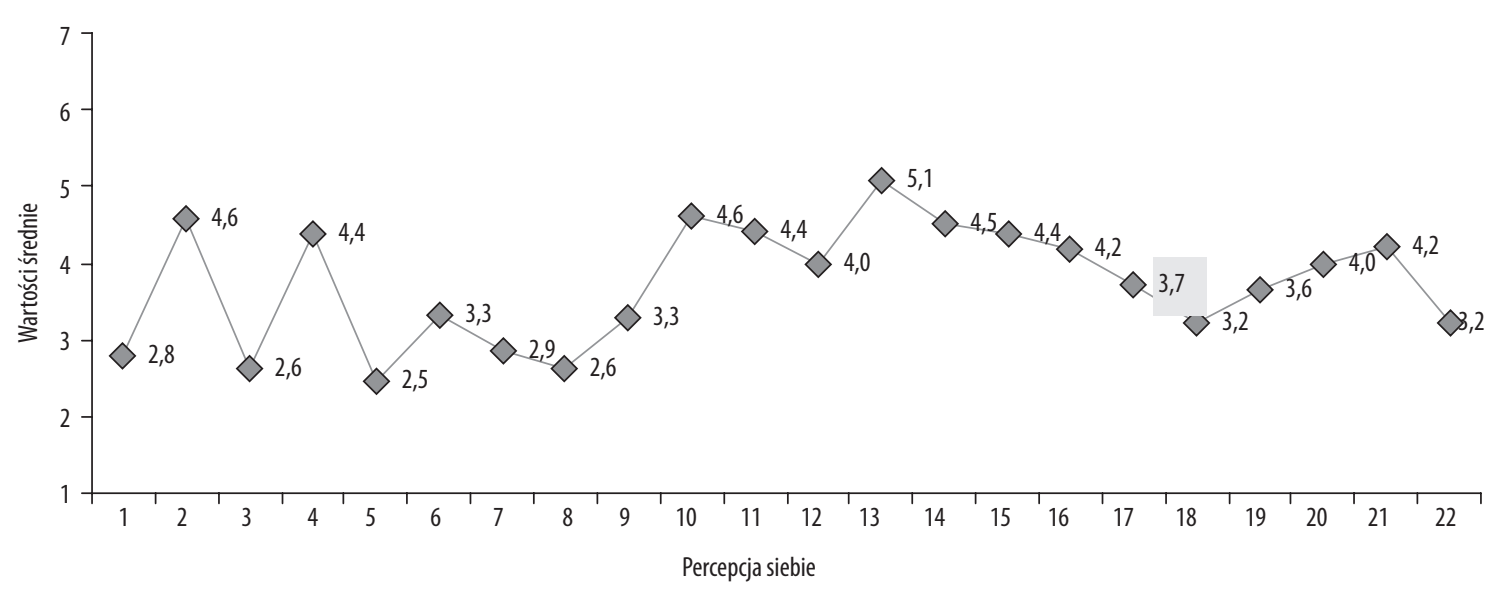

Rycina 4. Percepcja siebie - wyniki Kwestionariusza Ja-Inni (średnie) uzyskane przez osoby z głuchotą postlingwalną z implantem ślimakowym $(\mathrm{Cl})$ z wyodrębnieniem cechy Niepełnosprawny. 1 - Głupi, 2 - Dobry, 3 - Złośliwy, 4 - Pomysłowy, 5 - Słyszący, 6 - Słaby, 7 - Leniwy, 8 - Niesamodzielny, 9 - Nieprzystojny, 10 - Taktowny, 11 - Lubiany, 12 - Atrakcyjny fizycznie, 13 - Wrażliwy, 14 - Wesoły, 15 - Szczęśliwy, 16 - Towarzyski, 17 - Niepełnosprawny, 18 - Samotny, 19 - Nieśmiały, 20 - Nerwowy, 21 - Ja-Inni cechy pozytywne razem, 22 - Ja-Inni cechy negatywne razem

Figure 4. Self-perception - I-Others Questionnaire results (means) of the postlingually deaf Cl users, attribute Disability is isolated. 1 - Stupid, 2 - Good, 3 - Spiteful, 4 - Ingenious, 5 - Hearing, 6 - Weak, 7 - Lazy, 8 - Dependent, 9 - Unhandsome, 10 - Tactful, 11 - Likeable, 12 - Physically attractive, 13 - Sensitive, 14 - Cheerful, 15 - Happy, 16 - Sociable, 17 - Disabled, 18 - Lonely, 19 - Shy, 20 - Nervous, 21 - I-Others positive attributes total, 22 - I-Others negative attributes total

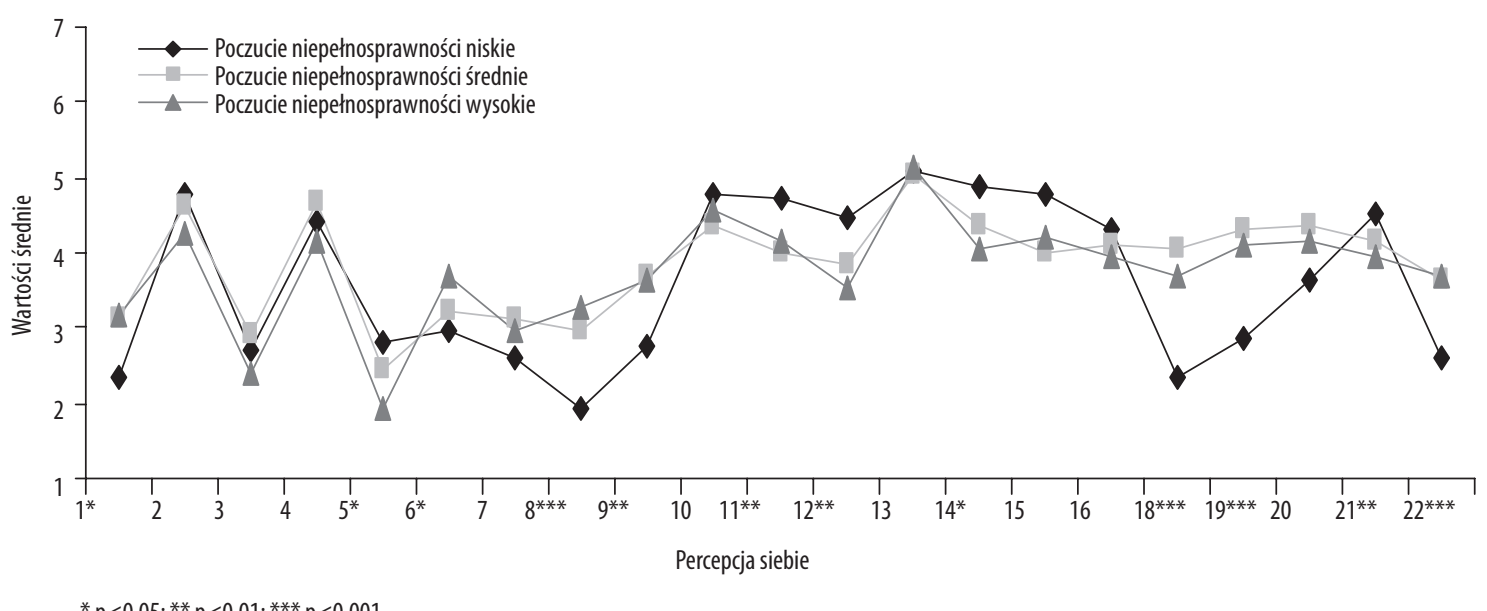

Rycina 5. Percepcja siebie - wyniki Kwestionariusza Ja-Inni (średnie) uzyskane przez osoby z głuchotą postlingwalną z implantem ślimakowym $(\mathrm{Cl})$ o niskim, średnim i wysokim poczuciu niepełnosprawności - porównania międzygrupowe wraz z istotnością różnic. 1 - Głupi, 2 - Dobry, 3 - Złośliwy, 4 - Pomysłowy, 5 - Słyszący, 6 - Słaby, 7 - Leniwy, 8 - Niesamodzielny, 9 - Nieprzystojny, 10 - Taktowny, 11 - Lubiany, 12 - Atrakcyjny fizycznie, 13 - Wrażliwy, 14 - Wesoły, 15 - Szczęśliwy, 16-Towarzyski, 17 - Niepełnosprawny, 18 - Samotny, 19 - Nieśmiały, 20 - Nerwowy, 21 - Ja-Inni cechy pozytywne razem, 22 - Ja-Inni cechy negatywne razem

Figure 5. Self-perception - I-Others Questionnaire results (means) of the postlingually deaf $\mathrm{Cl}$ users with low, medium and high level of the sense of disability - comparison of groups including significance of differences 1 - Stupid, 2 - Good, 3 - Spiteful, 4 - Ingenious, 5 - Hearing, 6 - Weak, 7 - Lazy, 8 - Dependent, 9 - Unhandsome, 10 - Tactful, 11 - Likeable, 12 - Physically attractive, 13 - Sensitive, 14 - Cheerful, 15 - Happy, 16 - Sociable, 17 - Disabled, 18 - Lonely, 19 - Shy, 20 - Nervous, 21 - I-Others positive attributes total, 22 - I-Others negative attributes total 
Tabela 4. Korelacje (r Pearsona) między poczuciem niepełnosprawności a percepcja siebie $\mathrm{W}$ odniesieniu do innych cech (Kwestionariusz Ja-Inni) u osób z głuchotą postlingwalną z implantem ślimakowym $(\mathrm{Cl})$

Table 4. Correlation (Pearson's r) between sense of disability and self-perception in relation to other attributes (I-Others Questionnaire) in the postlingually deaf $\mathrm{Cl}$ users

\begin{tabular}{|c|c|}
\hline $\begin{array}{c}\text { Percepcja siebie } \\
\text { (Kwestionariusz Ja-Inni) }\end{array}$ & $\begin{array}{l}\text { Poczucie niepełnosprawności } \\
\text { (r Pearsona) }\end{array}$ \\
\hline Głupi & $r=0,29 * *$ \\
\hline Dobry & $\begin{array}{l}r=0,16 \\
p=0,14\end{array}$ \\
\hline Złośliwy & $\begin{array}{l}r=-0,11 \\
p=0,32\end{array}$ \\
\hline Pomysłowy & $\begin{array}{l}r=-0,17 \\
p=0,12\end{array}$ \\
\hline Słyszący & $r=-0,31^{* *}$ \\
\hline Słaby & $r=0,36^{* *}$ \\
\hline Leniwy & $\begin{array}{l}r=0,11 \\
p=0,31\end{array}$ \\
\hline Niesamodzielny & $r=0,51^{* *}$ \\
\hline Nieprzystojny & $r=0,33^{* *}$ \\
\hline Taktowny & $\begin{array}{l}r=-0,12 \\
p=0,28\end{array}$ \\
\hline Lubiany & $r=-0,3^{* *}$ \\
\hline Atrakcyjny fizycznie & $r=-0,42^{* *}$ \\
\hline Wrażliwy & $\begin{array}{l}r=0,01 \\
p=0,9\end{array}$ \\
\hline Wesoły & $r=-0,37 * *$ \\
\hline Szczęśliwy & $r=-0,23^{*}$ \\
\hline Towarzyski & $\begin{array}{l}r=-0,13 \\
p=0,213\end{array}$ \\
\hline Samotny & $r=0,38^{* *}$ \\
\hline Nieśmiały & $r=0,39 * *$ \\
\hline Nerwowy & $\begin{array}{l}r=0,16 \\
p=0,13\end{array}$ \\
\hline Ja-inni pozytywne & $r=-0,41 * *$ \\
\hline Ja-inni negatywne & $r=0,62^{* *}$ \\
\hline
\end{tabular}

${ }^{*} p<0,05 ;{ }^{* *} p<0,01 ;{ }^{* *} p<0,001$

(nie zaś obiektywne ocenianym fizycznym funkcjonowaniem) a nasileniem objawów depresji została stwierdzona przykładowo u osób cierpiących na artretyzm [45]. Doświadczanie objawów depresji to kolejna właściwość psychologicznego funkcjonowania osoby, wchodząca w skład syndromu niepełnosprawności, których to przeżywanie może być udziałem osób $\mathrm{z}$ dowolną niepełnosprawnością czy chorobą.

Ograniczeniem badań jest dobór osób badanych, którymi byli wyłącznie uczestnicy hospitalizacji rehabilitacyjnych

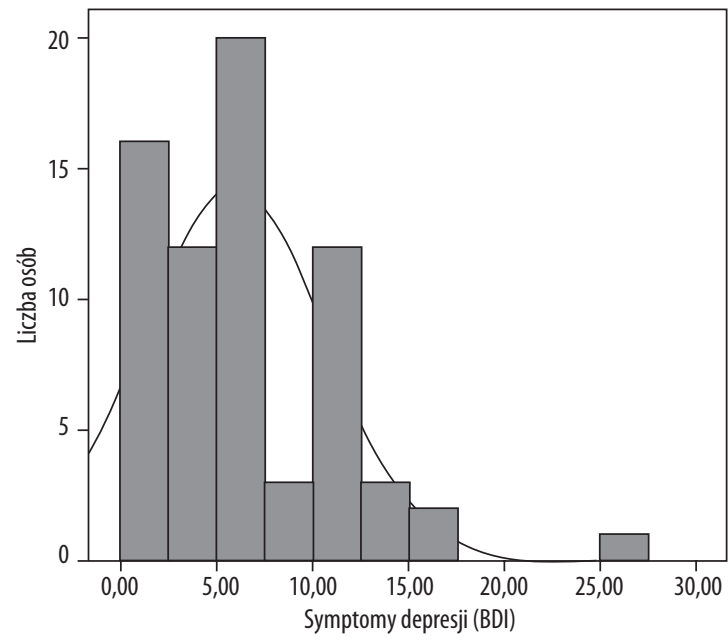

Rycina 6. Rozkład nasilenia symptomów depresji (Beck Depression Inventory, $B D I$ ) u osób z głuchotą postlingwalną z implantem ślimakowym (Cl)

Figure 6. Distribution of intensity of depression symptoms (Beck Depression Inventory, $B D I$ ) in the postlingually deaf $\mathrm{Cl}$ users

organizowanych dla pacjentów z głuchotą postlingwalną korzystających z implantu ślimakowego.

\section{Wnioski}

Poczucie niepełnosprawności wiąże się z doświadczaniem siebie w sposób specyficzny, także w innych wymiarach osobowej tożsamości, związanych $\mathrm{z}$ funkcjonowaniem poznawczym czy interpersonalnym, przez osoby ogłuchłe postlingwalnie. Okazuje się, że niepełnosprawność stanowi ważny wymiar doświadczania siebie w populacji osób postlingwalnie ogłuchłych $\mathrm{z}$ implantem ślimakowym, podobnie jak ma to miejsce u młodzieży prelingwalnie głuchej słyszących rodziców, niezależnie od tego, czy komunikuje się ona w języku migowym czy języku polskim fonicznym, co zostało stwierdzone we wcześniejszych badaniach [5]. Nabyta niepełnosprawność, w tym także głuchota, oznacza zatem konieczność ponownej integracji własnej osobowej tożsamości [46].

Utrata sprawności (tu: słuchu) jest niejednokrotnie doświadczeniem traumatycznym, które wymaga przepracowania „żalu po stracie” [47]. Osoby doświadczające nasilonego poczucia niepełnosprawności, zwłaszcza młodsze, tj. poniżej 60 lat, potrzebują różnych form interwencji psychologicznej, a także różnych form nieprofesjonalnego wsparcia (np. grupy wsparcia), by poradzić sobie z doznawanym cierpieniem i jego konsekwencjami. Sprzyja to stawaniu się osoba niepełnosprawną (głuchą), co wiąże się $\mathrm{z}$ doświadczaniem siebie i świata także w pozytywny sposób i włączeniem niepełnosprawności (głuchoty) w osobową tożsamość. Jak wskazują doświadczenia terapeutyczne w pracy z pacjentami z głuchotą nabytą, będącymi użytkownikami implantu ślimakowego, niewłaściwe jest założenie, iż naturalnie wraz z upływem czasu poradzą sobie oni sami i przystosują się do sytuacji utraty słuchu, jak i korzystania z implantu ślimakowego [18]. 
Załącznik 1.

KWESTIONARIUSZ „JA - INNI”

Przeczytaj uważnie listę wymienionych przez nas cech i odpowiedz, które z nich posiadasz w stopniu mniejszym lub większym niż inni ludzie.

Przy każdej z cech otocz kółkiem jedną z cyfr: 1, 2, 3, 4, 5, 6 lub 7.

Nie zapomnij o żadnej z cech!

Wydaje mi się, że w porównaniu z innymi ludźmi jestem:

\begin{tabular}{|c|c|c|c|c|c|c|c|}
\hline & $\begin{array}{c}\text { Dużo mniej } \\
\text { niż inni }\end{array}$ & $\begin{array}{l}\text { Mniej niż } \\
\text { inni }\end{array}$ & $\begin{array}{l}\text { Raczej mniej } \\
\text { niż inni }\end{array}$ & $\begin{array}{l}\text { Tak samo jak } \\
\text { inni }\end{array}$ & $\begin{array}{c}\text { Raczej } \\
\text { bardziej niż } \\
\text { inni }\end{array}$ & $\begin{array}{l}\text { Bardziej niż } \\
\quad \text { inni }\end{array}$ & $\begin{array}{c}\text { Dużo bardziej } \\
\text { niż inni }\end{array}$ \\
\hline & 1 & 2 & 3 & 4 & 5 & 6 & 7 \\
\hline 1. Gtupi & 1 & 2 & 3 & 4 & 5 & 6 & 7 \\
\hline 2. Dobry & 1 & 2 & 3 & 4 & 5 & 6 & 7 \\
\hline 3. Złośliwy & 1 & 2 & 3 & 4 & 5 & 6 & 7 \\
\hline 4. Pomysłowy & 1 & 2 & 3 & 4 & 5 & 6 & 7 \\
\hline 5. Styszący & 1 & 2 & 3 & 4 & 5 & 6 & 7 \\
\hline 6. Staby & 1 & 2 & 3 & 4 & 5 & 6 & 7 \\
\hline 7. Leniwy & 1 & 2 & 3 & 4 & 5 & 6 & 7 \\
\hline 8. Niesamodzielny & 1 & 2 & 3 & 4 & 5 & 6 & 7 \\
\hline 9. Nieprzystojny & 1 & 2 & 3 & 4 & 5 & 6 & 7 \\
\hline 10. Taktowny & 1 & 2 & 3 & 4 & 5 & 6 & 7 \\
\hline 11. Lubiany & 1 & 2 & 3 & 4 & 5 & 6 & 7 \\
\hline 12. Atrakcyjny fizycznie & 1 & 2 & 3 & 4 & 5 & 6 & 7 \\
\hline 13. Wrażliwy & 1 & 2 & 3 & 4 & 5 & 6 & 7 \\
\hline 14. Wesoły & 1 & 2 & 3 & 4 & 5 & 6 & 7 \\
\hline 15. Szczęśliwy & 1 & 2 & 3 & 4 & 5 & 6 & 7 \\
\hline 16. Towarzyski & 1 & 2 & 3 & 4 & 5 & 6 & 7 \\
\hline 17. Niepełnosprawny & 1 & 2 & 3 & 4 & 5 & 6 & 7 \\
\hline 18. Samotny & 1 & 2 & 3 & 4 & 5 & 6 & 7 \\
\hline 19. Nieśmiały & 1 & 2 & 3 & 4 & 5 & 6 & 7 \\
\hline 20. Nerwowy & 1 & 2 & 3 & 4 & 5 & 6 & 7 \\
\hline
\end{tabular}

Źródło: Kwestionariusz Ja-Inni (modyfikacja Kwestionariusza Cech wg M. Jarymowicz) został zaproponowany przez autorkę i opublikowany w: J. Kobosko - Tożsamość macierzyńska słyszących matek młodzieży głuchej i jej znaczenie dla rozwoju osobowej tożsamości tej młodzieży. Nieopublikowana rozprawa doktorska. Warszawa: Uniwersytet Warszawski, Wydział Psychologii; 2007.

\section{Piśmiennictwo:}

1. Szymczak B. Słownik języka polskiego, t. II. Warszawa: Państwowe Wydawnictwo Naukowe; 1979.

2. Mosby S. Mosby's Medical Dictionary, wyd. 8, e-book; 2009.

3. Helvik A-S, Jacobsen G, Hallberg LR-M. Psychological well-being of adults with acquired hearing impairment. Disabil Rehabil, 2006; 28(9): 535-45.

4. Wilmowska-Pietruszyńska A, Bilski D. Międzynarodowa Klasyfikacja Funkcjonowania, Niepełnosprawności i Zdrowia. Niepełnosprawność - zagadnienia, problemy, rozwiązania, 2013; 2(7): 5-20.
5. Kobosko J. Osoba głucha, to znaczy kto? - tożsamość osobowa młodzieży głuchej i słabosłyszącej rodziców słyszących. W: Kobosko J, red. Młodzież głucha i słabosłysząca w rodzinie i otaczającym świecie - dla terapeutów, nauczycieli, wychowawców i rodziców. Warszawa: Stowarzyszenie „Usłyszeć Świat"; 2009, 19-35.

6. Kobosko J. Doświadczanie siebie jako osoby głuchej - badania nad młodzieżą głuchą i jej słyszącymi matkami z perspektywy interpersonalnej. Człowiek - Niepełnosprawność - Społeczeństwo, 2010; 11: 101-22. 
7. Krawiec M. Poczucie niepełnosprawności u młodzieży z uszkodzeniami słuchu. W: Kobosko J, red. Młodzież głucha i słabosłysząca w rodzinie i otaczającym świecie - dla terapeutów, nauczycieli, wychowawców i rodziców. Warszawa: Stowarzyszenie „Usłyszeć Świat”; 2009, 67-78.

8. Kobosko J. Tożsamość macierzyńska matki a głuchota dziecka. Studia nad matkami słyszącymi młodzieży głuchej. Studia Psychologiczne, 2008; 46(3): 35-50.

9. De Graaf R, Bijl RV. Determinants of mental distress in adults with a severe auditory impairment: differences between prelingual and postlingual deafness. Psychosom Med, 2002; 64(1): 61-70.

10. Malinoff RL, Weinstein BE. Changes in self-assessment of hearing handicap over the first year of hearing aid use by older adults. J Speech Lang Hear Res, 1989; 22: 54-60.

11. Saito H, Nishiwaki Y, Michikawa T, Kikuchi Y, Mizutari K, Takebayashi T i wsp. Hearing handicap predicts the development of depressive symptoms after 3 years in older community-dwelling Japanese. J Am Geriatr Soc, 2010; 58: 93-7.

12. Gopinath B, Schneider J, Hickson L, McMahon CM, Burlutsky G, Leeder SR i wsp. Hearing handicap, rather than measured hearing impairment, predicts poorer quality of life over 10 years in older adults. Maturitas, 2012; 72(2): 146-51.

13. Bench RJ. Communication skills in hearing-impaired children. London: Whurr Publishers; 1992.

14. Du Feu M, Fergusson K. Sensory impairment and mental health. Advances in Psychiatric Treatment, 2003; 9: 95-103.

15. Barlow JH, Turner AP, Hammond CL, Gailey L. Living with late deafness: insight from between worlds. Int J Audiol, 2007; 46: 442-8.

16. Szczepankowski B. Niesłyszący - głusi - głuchoniemi. Wyrównywanie szans. Warszawa: WSiP; 1999.

17. Hallberg LR-M, Ringdahl A. Living with cochlear implants: experiences of 17 adult patients in Sweden. Int J Audiol, 2004; 43: 115-21.

18. Heydebrand G, Mauze E, Tye-Murray N, Binzer S, Skinner M. The efficacy of structured group therapy intervention in improving communication and coping skills for adult cochleaar implant recipients. Int J Audiol, 2005; 44: 272-80.

19. Kobosko J. Aparat słuchowy - aspekty psychologiczne, społeczne i komunikacyjne. W: Kobosko J, red. Młodzież głucha i słabosłysząca w rodzinie i otaczającym świecie - dla terapeutów, nauczycieli, wychowawców i rodziców. Warszawa: Stowarzyszenie „Usłyszeć Świat”; 2009, 237-46.

20. Tambs K. Moderate effects of hearing loss on mental health and subjective well-being: Results from the Nord-Trøndelag Hearing Loss Study. Psychosom Med, 2004; 66: 776-82.

21. Veale H, Gill L, Guang NGS, Lind C, Bond MJ. Self-reported hearing handicap and mental health in Australia: Some preliminary findings. Australian and New Zealand Journal of Audiology, 2010; 32(2): 106-14.

22. Fellinger J, Holzinger D, Pollard R. Mental health of deaf people. Lancet, 2012; 379: 1037-44.

23. Williams KC, Falkum E, Martinsen EW. Fear of negative evaluation, avoidance and mental distress among hearing-impaired employees. Rehab Psychol, 2015; 60(1): 51-8.

24. Tomaszewski P, Bargiel-Matusiewicz K, Pisula E. Między patologią a kulturą: społeczne uwarunkowania niepełnosprawności - wprowadzenie. W: Tomaszewski P, Bargiel-Matusiewicz K, Pisula E, red. Kulturowe i społeczne aspekty niepełnosprawności. Warszawa: Wydawnictwo Uniwersytetu Warszawskiego; 2015, 9-17.
25. Krabbe PF, Hinderink JB, Van den Broek P. The effect of cochlear implant use in postlingually deaf adults. Int J Technol Assess Health Care, 2000; 16: 864-73.

26. Mo B, Lindbaek M, Harris S. Cochlear implants and quality of life: a prospective study. Ear Hear, 2005; 26: 186-94.

27. Lassaleta L, Castro A, Bastarrica M, Jose de Sarria M, Gavilan J. Quality of life in postlingually deaf patients following cochlear implantation. Eur Arch Otorhinolaryngol, 2006; 263(3): 267-70.

28. Rostkowska J, Wojewódzka B, Kobosko J, Geremek-Samsonowicz A, Skarżyński H. Możliwości słuchowe dorosłych osób ogłuchłych zaopatrzonych w implant ślimakowy. Nowa Audiofonologia, 2012; 1(1): 46-9.

29. Skarżyński H, Janczewski G, Niemczyk K, Geremek A, Kochanek K, Klasek O. Pierwszy wszczep ślimakowy w Polsce. Otolaryngol Pol, 1993; 47: 427-34.

30. Juczyński Z, Ogińska-Bulik N. Osobowość, stres a zdrowie. Warszawa: Difin; 2010.

31. Eriksson-Mangold M, Carlsson SG. Psychological and somatic distress in relation to perceived hearing disability, hearing handicap, and hearing measurements. J Psychosom Res, 1991; 35: 729-40.

32. Hallam R, Ashton P, Sherbourne K, Gailey L. Acquired profound hearing loss: Mental health and other characteristics of a large sample. Int J Audiol, 2006; 45: 715-23.

33. Rembar SH, Lind O, Romundstad P, Helvik A-S. Psychological well-being among cochlear implant users: A comparison with the general population. Cochlear Implants Int, 2012; 13: 41-8.

34. Kobosko J, Piłka E, Jędrzejczak WW, Pankowska A, Skarżyński H. Mental health and postlingually deaf adults cochlear implant users. $6^{\text {th }}$ World Congress on Mental Health and Deafness (WCMHD) „Pathways to rights”, Belfast, United Kingdom, 2014. Abstract book.

35. Manchaiah VKC, Stephens D. Perspectives on defining "hearing loss" and its consequences. Hear Balanc Commun, 2013; 11: 6-16.

36. Kobosko J. Tożsamość macierzyńska słyszących matek młodzieży głuchej i jej znaczenie dla rozwoju osobowej tożsamości tej młodzieży. Nieopublikowana rozprawa doktorska. Warszawa: Uniwersytet Warszawski, Wydział Psychologii; 2007.

37. Jarymowicz M. Komunikacja ustna. Warszawa: Uniwersytet Warszawski, Wydział Psychologii; 2004.

38. Kobosko J, Szuchnik J, Wojda P. Kwestionariusz Ja-Inni jako narzędzie służące do opisu tożsamości własnej młodzieży głuchej. Audiofonologia, 2004; 26: 119-33.

39. Beck AT, Hammen CL, Hollon SD, Ingram RE, Kendall PC. Issuses and recommendations regarding use of the Beck Depression Inventory. Cognitive Ther Res, 1987; 11: 289-99.

40. Zawadzki B, Popiel A, Pragłowska E. Charakterystyka psychometryczna polskiej adaptacji Kwestionariusza Depresji BDI-II Aarona T. Becka. Psychologia - Etologia - Genetyka, 2009; 19: $71-5$.

41. Lis-Turlejska M, Szumiał S, Okuniewska H. Aktualny poziom objawów stresu potraumatycznego w próbie osób, które w dzieciństwie przeżyły II wojnę światową. Psych Pol, 2012; 46(2): 145-56

42. Bartczak M, Bokus B. Rozumienie pojęć w depresji. Piaseczno: Studio LEXEM; 2013.

43. Beck AT, Steer RA, Garbin MG. Psychometric properties of the Beck Depression Inventory: Twenty-five years of evaluation. Clin Psychol Rev, 1988; 8(1): 77-100. 
44. Kobosko J, Pankowska A, Skarżyński H. Strategie radzenia sobie ze stresem u osób dorosłych z głuchotą postlingwalną korzystających $\mathrm{z}$ implantu ślimakowego w porównaniu $\mathrm{z}$ populacją ogólną słyszących. Otolaryngol Pol, 2012; 66: 132-7.

45. Becofsky K, Baruth M, Wilcos S. Physical functioning, perceived disability, and depressive symptoms in adults with arthritis. Arthritis, 2013; 2013: 525761.
46. Wolski P. Utrata sprawności. Radzenie sobie z niepełnosprawnością nabytą a aktywizacja zawodowa. Warszawa: Wydawnictwo Naukowe SCHOLAR; 2010.

47. Briere J, Sott C. Podstawy terapii traumy. Diagnoza i metody terapeutyczne, tłum. P. Nowak. Warszawa: Instytut Psychologii Zdrowia PTP; 2010. 